\title{
PENGARUH KEPEMILIKAN INSTITUSIONAL, KEPEMILIKAN \\ MANAJERIAL, KOMISARIS INDEPENDEN, DAN UKURAN DEWAN \\ KOMISARIS TERHADAP MANAJEMEN LABA SERTA IMPLIKASINYA \\ TERHADAP KINERJA KEUANGAN PADA PERUSAHAAN MANUFAKTUR YANG TERDAFTAR DI BURSA EFEK INDONESIA PERIODE 2012-2014
}

\author{
Shierly Pricilia, dan Liana Susanto \\ Fakultas Ekonomi Universitas Tarumanagara \\ lia_2309@yahoo.com
}

\begin{abstract}
The purpose of this study is to analyze the effect of institusional ownership, managerial ownership, independent commissioner, and board of size on earning management and the implication on financial performance of manufacturing companies listed in the Indonesian Stock Exchange from 2012-2014. This research used the data of manufacturing companies that were selected using purposive sampling method for a total of 73 data in three years. Statistic method used in this study is multiple regression analysis and simple regression analysis. The data used in this research are secondary data in the form of financial statements that published during the observation year. The results of this study showed that earning management significantly affected by managerial ownership, and independent commissioner. Financial performance showed that significantly affected by earning management.
\end{abstract}

Keywords: Institusional ownership, managerial ownership, independent commissioner, board of size, earning management, financial performance

\begin{abstract}
Abstrak: Tujuan penelitian ini adalah untuk menganalisis pengaruh dari kepemilikan institusional, kepemilikan manajerial, komisaris independen, dan ukuran dewan komisaris terhadap manajemen laba serta implikasinya terhadap kinerja keuangan pada perusahaan manufaktur yang terdaftar di Bursa Efek Indonesia (BEI) periode 2012-2014. Penelitian ini menggunakan data perusahaan manufaktur yang telah diseleksi menggunakan metode purposive sampling dengan total 73 data selama tiga tahun. Metode statistik yang digunakan dalam penelitian ini adalah analisis regresi linear berganda dan analisis regresi linier sederhana. Data yang digunakan adalah data sekunder, seperti laporan keuangan yang telah dipublikasikan selama tahun penelitian. Hasil penelitian menunjukkan bahwa kepemilikan manajerial dan ukuran dewan komisaris berpengaruh signifikan terhadap manajemen laba serta manajemen laba memiliki pengaruh signifikan terhadap kinerja keuangan.
\end{abstract}

Kata kunci: Kepemilikan institusional, kepemilikan manajerial, komisaris independen, ukuran dewan komisaris, manajemen laba, kinerja keuangan

\section{PENDAHULUAN}

Menurut Iqbal (2007), laporan keuangan seringkali disalahgunakan oleh manajemen dengan melakukan perubahan dalam penggunaan metode akuntansi, sehingga akan mempengaruhi jumlah laba yang ditampilkan dalam laporan keuangan. Hal ini sering dikenal dengan istilah manajemen laba. Manajemen laba merupakan suatu tindakan yang 
dilakukan oleh pihak manajemen yang dapat mempengaruhi tingkat laba yang ditampilkan.

Manajemen laba merupakan masalah keagenan yang sering dipicu oleh adanya pemisahan peran atau perbedaan kepentingan antara pemegang saham dengan manajemen perusahaan. Kedua pihak tersebut berupaya untuk lebih mengutamakan kepentingannya masing-masing dari pada kepentingan perusahaan. Sebagai agen, manajer bertanggung jawab untuk mengoptimalkan laba para pemilik (principal). Namun dilain pihak, manajer tersebut juga mempunyai kepentingan untuk memaksimalkan kesejahteraan. Fisher dan Rosenzweig (dalam Sulistyanto, 2008), menyebutkan bahwa manajemen laba adalah tindakan-tindakan manajer untuk menaikkan (menurunkan) laba periode berjalan dari sebuah perusahaan yang dikelolanya tanpa menyebabkan kenaikan (penurunan) keuntungan ekonomi perusahaan jangka panjang.

Tahun 2001 tercatat skandal keuangan di perusahaan publik yang melibatkan manipulasi laporan keuangan oleh PT Lippo Tbk dan PT Kimia Farma Tbk (Boediono, 2005). Salah satu penyebab kondisi ini adalah kurangnya penerapan corporate governance. Alijoyo, et al. (dalam Nasution dan Doddy, 2007) menyebutkan bahwa lemahnya praktik corporate governance di Indonesia mengarah pada defisiensi pembuatan keputusan dalam perusahaan dan tindakan perusahaan.

Penerapan Good Corporate Governance $(G C G)$ pada saat ini bukan lagi sekedar kewajiban, namun telah menjadi kebutuhan bagi setiap perusahaan dan organisasi. Good Corporate Governance (GCG) diperlukan untuk memberikan kemajuan terhadap kinerja suatu perusahaan, menjadikan perusahaan berumur panjang dan bisa dipercaya. Good corporate governance memberikan perlindungan efektif bagi pemegang saham dan kreditor sehingga mereka yakin akan memperoleh return atas investasinya dengan benar.

Good Corporate Governanace merupakan salah satu elemen kunci dalam meningkatkan efesiensi ekonomis, yang meliputi serangkaian hubungan antara manajemen perusahaan, dewan komisaris, para pemegang saham dan stakeholders. Darmawati, Khomsiyah dan Rika (2005) menyatakan bahwa Good Corporate Governance juga memberikan suatu struktur yang memfasilitasi penentuan sasaran-sasaran dari suatu perusahaan, dan sebagai sarana untuk menentukan teknik monitoring kinerja.

Perilaku manipulasi oleh manajer yang berawal dari konflik kepentingan dapat diminimumkan melalui suatu mekanisme monitoring yang bertujuan untuk menyelaraskan berbagai kepentingan. Pertama, Jensen dan Meckling (dalam Ujiyantho dan Bambang, 2007) menyatakan dengan memperbesar kepemilikan saham perusahaan oleh manajemen (managerial ownership), sehingga kepentingan pemilik atau pemegang saham akan dapat disejajarkan dengan kepentingan manajer. Kedua, kepemilikan saham oleh investor institusional. Moh'd et al. (dalam Ujiyantho dan Bambang, 2007) menyatakan bahwa investor institusional merupakan pihak yang dapat memonitor agen dengan kepemilikannya yang besar, sehingga motivasi manajer untuk mengatur laba menjadi berkurang. Ketiga, melalui peran monitoring oleh dewan komisaris (board of directors). Dechow dan Beasly (dalam Ujiyantho dan Bambang, 2007) menemukan hubungan yang signifikan antara peran dewan komisaris dengan pelaporan keuangan, dimana ukuran dan independensi dewan komisaris mempengaruhi kemampuannya dalam memonitor proses pelaporan keuangan.

Dalam kaitannya dengan dengan kinerja keuangan, laporan keuangan menjadi patokan untuk mengukur bagaimana kinerja suatu perusahaan itu dikatakan baik. Kinerja perusahaan merupakan suatu gambaran tentang kondisi keuangan suatu perusahaan yang 
dianalisis dengan alat-alat analisis keuangan, sehingga dapat diketahui mengenai baik buruknya keadaan keuangan suatu perusahaan yang mencerminkan prestasi kerja dalam periode tertentu. Salah satu jenis laporan keuangan yang mengukur keberhasilan operasi perusahaan untuk suatu periode tertentu adalah laporan laba rugi. Akan tetapi angka laba yang dihasilkan dalam laporan laba rugi seringkali dipengaruhi oleh metode akuntansi yang digunakan (Kieso dan Weygandt, 2007), sehingga laba yang tinggi belum tentu mencerminkan kas yang besar. Dalam hal ini arus kas mempunyai nilai lebih untuk menjamin kinerja perusahaan di masa mendatang. Pradhono dan Christiawan (2005) menyatakan arus kas (Cash Flow) menunjukkan hasil operasi yang dananya telah diterima tunai oleh perusahaan serta dibebani dengan beban yang bersifat tunai dan benar-benar sudah dikeluarkan oleh perusahaan.

Menurut Cornett, et al (2006), Cash Flow Return on Assets (CFROA) merupakan salah satu pengukuran kinerja perusahaan yang menunjukkan kemampuan aktiva perusahaan untuk menghasilkan laba operasi. CFROA lebih memfokuskan pada pengukuran kinerja perusahaan saat ini dan CFROA tidak terikat dengan harga saham.

Laporan keuangan sebagai produk informasi yang dihasilkan perusahaan, tidak terlepas dari proses penyusunannya. Kebijakan dan keputusan yang diambil dalam rangka proses penyusunan laporan keuangan akan mempengaruhi penilaian kinerja perusahaan. Menurut Dwi (2005) manajemen laba merupakan salah satu faktor yang mempengaruhi kinerja perusahaan. Manajemen akan memilih metode tertentu untuk mendapatkan laba yang sesuai dengan motivasinya.

Hasil penelitian sebelumnya yang dilakukan oleh Ujiyantho dan Bambang (2007) menunjukkan bahwa kepemilikan institusional tidak berpengaruh signifikan terhadap manajemen laba, sedangkan pada penelitian Asrori dan Bowo (2014) menunjukkan bahwa kepemilikan institusional berpengaruh signifikan terhadap manajemen laba.

Hasil penelitian Ujiyantho dan Bambang (2007) menunjukkan bahwa kepemilikan manajerial berpengaruh signifikan terhadap manajemen laba, sedangkan hasil penelitian Guna dan Arleen (2010) menunjukkan bahwa kepemilikan manajerial tidak berpengaruh signifikan terhadap manajemen laba.

Hasil penelitian Ujiyantho dan Bambang (2007) menunjukkan bahwa komisaris independen berpengaruh signifikan terhadap manajemen laba, sedangkan penelitian Guna dan Arleen (2010) menunjukkan bahwa komisaris independen tidak berpengaruh siginifkan terhadap manajemen laba.

Hasil penelitian Ujiyantho dan Bambang (2007) menunjukkan bahwa ukuran dewan komisaris tidak berpengaruh siginifikan terhadap manajemen laba, sedangkan penelitian Nasution dan Setiwan (2007) menunjukkan bahwa ukuran dewan komisaris berpengaruh signifikan terhadap manajemen laba.

Hasil penelitian Ujiyantho dan Bambang (2007) menunjukkan bahwa manajemen laba tidak berpengaruh signifikan terhadap kinerja keuangan, sedangkan penelitian Dwi (2005) menunjukkan bahwa manajemen laba berpengaruh signifikan terhadap kinerja keuangan.

\section{KAJIAN TEORI}

Teori Keagenan (Agency Theory). Jensen dan Meckling (dalam Luayyi, 2010) mendefinisikan hubungan keagenan (agency relationship) sebagai suatu kontrak antara pemilik (principal) dengan manajer (agent) untuk menjalankan suatu tugas demi kepentingan pemilik (principal) dengan mendelegasikan wewenang pengambilan 
keputusan kepada manajer (agent). Dalam prakteknya manajer sebagai pengelola perusahaan tentunya mengetahui lebih banyak informasi internal dan prospek perusahaan di waktu mendatang dibandingkan pemilik modal atau pemegang saham. Sehingga sebagai pengelola, manajer memiliki kewajiban memberikan informasi mengenai kondisi perusahaan kepada pemilik. Tetapi dalam hal ini informasi yang disampaikan oleh manajer terkadang tidak sesuai dengan kondisi perusahaan yang sebenarnya.

Pihak principal termotivasi mengadakan kontrak untuk menyejahterakan diri dengan profitabilitas yang selalu meningkat. Agent termotivasi untuk memaksimalkan pemenuhan kebutuhan ekonomi, antara lain dalam hal memperoleh investasi, pinjaman, maupun kontrak kompensasi. Widyaningdyah (dalam Wisnu, 2013) menyatakan konflik kepentingan semakin meningkat terutama karena principal tidak dapat memonitor aktivitas agent sehari-hari untuk memastikan bahwa agent bekerja sesuai dengan keinginan pemegang saham.

Principal tidak memiliki informasi yang cukup tentang kinerja agent. Agent mempunyai lebih banyak informasi mengenai kapasitas diri, lingkungan kerja, dan perusahaan secara keseluruhan. Hal inilah yang mengakibatkan adanya ketidakseimbangan informasi yang dimiliki oleh principal dan agent. Widyaningdyah (dalam Wisnu, 2013) menyatakan ketidakseimbangan informasi inilah yang disebut dengan asimetri informasi. Asimetri informasi dan konflik kepentingan yang terjadi antara principal dan agent mendorong agent untuk menyajikan informasi yang tidak sebenarnya kepada principal, terutama jika informasi tersebut berkaitan dengan pengukuran kinerja agent. Asimetri informasi antara manajemen (agent) dengan pemilik (principal) dapat memberikan kesempatan kepada manajer untuk melakukan manajemen laba (earnings management) dalam rangka menyesatkan pemilik (pemegang saham) mengenai kinerja ekonomi perusahaan.

Corporate governance yang merupakan konsep yang didasarkan pada teori keagenan, diharapkan bisa berfungsi sebagai alat untuk memberikan keyakinan kepada para investor bahwa mereka akan menerima return atas dana yang telah mereka investasikan. Shleifer dan Vishny (dalam Ujiyantho dan Bambang, 2007) menyatakan corporate governance berkaitan dengan bagaimana para investor yakin bahwa manajer akan memberikan keuntungan bagi mereka, yakin bahwa manajer tidak akan mencuri/menggelapkan atau menginvestasikan ke dalam proyek-proyek yang tidak menguntungkan berkaitan dengan dana/kapital yang telah ditanamkan oleh investor, dan berkaitan dengan bagaimana para investor mengontrol para manajer. Corporate governance diharapkan dapat berfungsi untuk menekan atau menurunkan biaya keagenan (agency cost).

Manajemen Laba. Manajemen laba didefinisikan sebagai upaya manajer perusahaan untuk mempengaruhi informasi dalam laporan keuangan dengan tujuan untuk mengelabui stakeholder yang ingin mengetahui kinerja dan kondisi perusahaan (Sulistyanto, 2008). Schipper (dalam Subramanyam, 2010) menyebutkan bahwa manajemen laba merupakan intervensi manajemen dengan sengaja dalam proses penentuan laba, biasanya untuk memenuhi kebutuhan pribadi.

Menurut Sugiri (dalam Wisnu, 2013) membagi definisi manajemen laba menjadi dua, yaitu definisi luas earnings management merupakan tindakan manajer untuk meningkatkan (mengurangi) laba yang dilaporkan saat ini atas suatu unit dimana manajer bertanggung jawab, tanpa mengakibatkan peningkatan (penurunan) profitabilitas ekonomis jangka panjang unit tersebut. 
Definisi sempit earning management dalam hal ini hanya berkaitan dengan pemilihan metode akuntansi. Earning management dalam arti sempit didefinisikan sebagai perilaku manajer untuk "bermain" dengan komponen discretionary accrual dalam menentukan besarnya earning. Healy dan Wahlen (dalam Wisnu, 2013) menyatakan bahwa manajemen laba muncul ketika manajer menggunakan keputusan tertentu dalam pelaporan keuangan untuk menyesatkan stakeholder yang ingin mengetahui kinerja ekonomi yang diperoleh perusahaan.

Manajemen laba dilakukan oleh manajer pada faktor-faktor fundamental perusahaan, yaitu dengan intervensi pada penyusunan laporan keuangan berdasarkan akuntansi akrual. Cornett, et al. (dalam Ujiyantho dan Bambang, 2007) menemukan adanya pengaruh mekanisme corporate governance terhadap penurunan discretionary accruals sebagai ukuran dari manajemen laba dan berhubungan dengan kinerja keuangan. Mekanisme corporate governance dapat mengurangi dorongan manajer melakukan earnings management, sehingga kinerja keuangan yang dilaporkan merefleksikan keadaan yang sebenarnya.

Untuk menilai kinerja keuangan perusahaan dapat dilihat dari segi analisis laporan keuangan dan dari segi perubahan saham. Tujuan dari penilaian kinerja adalah untuk memberi motivasi pada karyawan dalam mencapai target organisasi dan dalam mematuhi standar perilaku yang telah ditetapkan perusahaan agar dapat membuahkan hasil dan tindakan yang diharapkan (Najib, 2010).

Good Corporate Governance (GCG). Wibisono (dalam Guna dan Arleen, 2010) mengemukakan bahwa Good Corporate Governance atau tata kelola perusahaan yang baik dapat didefinisikan sebagai sistem yang mengatur dan mengendalikan perusahaan untuk menciptakan nilai tambah bagi setiap stakeholders. Ada dua hal yang ditekankan dalam mekanisme ini, pertama pentingnya hak pemegang saham untuk memperoleh informasi dengan benar (akurat) dan tepat pada waktunya, dan kedua, kewajiban perusahaan untuk melakukan pengungkapan secara akurat, tepat waktu dan transparan terhadap semua informasi kinerja perusahaan, kepemilikan dan stakeholders.

Pengaruh Kepemilikan Institusional terhadap Manajemen Laba. Kepemilikan institusional adalah kepemilikan saham perusahaan yang dimiliki oleh institusi atau lembaga seperti perusahaan asuransi, bank dan kepemilikan institusi lain (Tarjo, 2008). Kepemilikan institusional memiliki arti penting dalam memonitor manajemen karena dengan adanya kepemilikan oleh institusional akan mendorong peningkatan pengawasan yang lebih optimal. Monitoring tersebut tentunya akan menjamin kemakmuran untuk pemegang saham, pengaruh kepemilikan institusional sebagai agen pengawas ditekan melalui investasi mereka yang cukup besar dalam pasar modal. Tingkat kepemilikan institusional yang tinggi akan menimbulkan usaha pengawasan yang lebih besar oleh pihak investor institusional sehingga dapat menghalangi perilaku opportunistic manajer (Purwandari, 2011).

Kepemilikan institusional memiliki kemampuan untuk mengendalikan pihak manajemen melalui proses monitoring secara efektif sehingga dapat mengurangi manajemen laba. Persentase saham tertentu yang dimiliki oleh institusi dapat mempengaruhi proses penyusunan laporan keuangan yang tidak menutup kemungkinan terdapat akrualisasi sesuai kepentingan pihak manajemen (Gideon, 2005). 
Cornett, et al. (dalam Ujiyantho dan Bambang, 2007) menyatakan bahwa tindakan pengawasan yang dilakukan oleh sebuah perusahaan dan pihak investor insitusional dapat membatasi perilaku para manajer. Tindakan pengawasan perusahaan oleh pihak investor institusional dapat mendorong manajer untuk lebih memfokuskan perhatiannya terhadap kinerja perusahaan sehingga akan mengurangi perilaku opportunistic atau mementingkan diri sendiri.

H1: Kepemilikan institusional berpengaruh signifikan terhadap manajemen laba

Pengaruh Kepemilikan Manajerial terhadap Manajemen Laba. Kepemilikan manajerial adalah saham yang dimiliki oleh manajemen secara pribadi maupun yang dimiliki oleh anak cabang perusahaan bersangkutan beserta afiliasi (Susiana dan Herawaty, 2007). Investor institusional dan manajemen memiliki insentif yang kuat untuk mendapatkan informasi pra pengungkapan (predisclosure information) mengenai perusahaan untuk memenuhi tanggung jawab serta untuk meningkatkan kinerja portofolio.

Manajemen laba sangat ditentukan oleh motivasi manajer perusahaan. Motivasi yang berbeda akan menghasilkan besaran manajemen laba yang berbeda, seperti antara manajer yang juga sekaligus sebagai pemegang saham dan manajer yang tidak sebagai pemegang saham. Dua hal tersebut akan mempengaruhi manajemen laba, sebab kepemilikan seorang manajer akan ikut menentukan kebijakan dan pengambilan keputusan pada perusahaan yang mereka kelola. Secara umum dapat dikatakan bahwa persentase tertentu kepemilikan saham oleh pihak manajemen cenderung mempengaruhi tindakan manajemen laba (Gideon, 2005).

H2: Kepemilikan manajerial berpengaruh signifikan terhadap manajemen laba

Pengaruh Komisaris Independen terhadap Manajemen Laba. Menurut UndangUndang Republik Indonesia No. 40 tahun 2007 pasal 120 ayat 2, komisaris independen diangkat berdasarkan keputusan RUPS dari pihak yang tidak terafiliasi dengan pemegang saham utama, anggota direksi dan/ atau anggota dewan komisaris lainnya.

Fama dan Jensen (dalam Ujiyantho dan Bambang, 2007) menyatakan bahwa nonexecutive director (komisaris independen) dapat bertindak sebagai penengah dalam perselisihan yang terjadi diantara para manajer internal dan mengawasi kebijakan manajemen serta memberikan nasihat kepada manajemen. Komisaris independen merupakan posisi terbaik untuk melaksanakan fungsi monitoring agar tercipta perusahaan yang good corporate governance.

Secara umum dewan komisaris ditugaskan dan diberi tanggung jawab atas pengawasan kualitas informasi yang terkandung dalam laporan keuangan. Hal ini penting mengingat adanya kepentingan dari manajemen untuk melakukan manajemen laba yang berdampak pada berkurangnya kepercayaan investor. Untuk mengatasinya dewan komisaris diperbolehkan untuk memiliki akses pada informasi perusahaan. Dewan komisaris tidak memiliki otoritas dalam perusahaan, maka dewan direksi bertanggung jawab untuk menyampaikan informasi terkait dengan perusahaan kepada dewan komisaris. Wallace dan Peter (dalam Ujiyantho dan Bambang, 2007) memberikan simpulan bahwa perusahaan yang memiliki proporsi anggota dewan komisaris yang berasal dari luar perusahaan atau outside director dapat mempengaruhi tindakan manajemen laba. Sehingga, jika anggota dewan komisaris dari luar meningkatkan tindakan pengawasan, hal ini juga akan berhubungan dengan makin rendahnya tindakan manajemen laba.

H3: Komisaris independen berpengaruh signifikan terhadap manajemen laba 
Pengaruh Ukuran Dewan Komisaris terhadap Manajemen Laba. Menurut Moenaf dalam Emrinaldi (2007), dewan komisaris berasal dari tanggung jawab pengaturan (governnce) suatu badan usaha yang dimiliki oleh kelompok orang yang berbeda dengan pengelola. Peran dari dewan komisaris adalah melakukan monitoring dari implementasi kebijakan direksi.

Jensen dan Lipton (dalam Ujiyantho dan Bambang, 2007) menyimpulkan bahwa ukuran dewan komisaris merupakan bagian dari mekanisme corporate governance. Hal ini diperkuat oleh pendapat Allen dan Gale (dalam Ujiyantho dan Bambang, 2007) yang menegaskan bahwa dewan komisaris merupakan mekanisme governance yang penting.

Dewan komisaris yang berukuran kecil akan lebih efektif dalam melakukan tindakan pengawasan dibandingkan dewan komisaris berukuran besar. Ukuran dewan komisaris yang besar dianggap kurang efektif dalam menjalankan fungsinya karena sulit dalam komunikasi, koordinasi serta pembuatan keputusan.

H4: Ukuran dewan komisaris berpengaruh signifikan terhadap manajemen laba

Pengaruh Manajemen Laba terhadap Kinerja Keuangan. Laporan keuangan sebagai produk informasi yang dihasilkan perusahaan, tidak terlepas dari proses penyusunannya. Berbagai kebijakan dan keputusan yang diambil oleh pihak manajemen dalam rangka proses penyusunan laporan keuangan nantinya akan mempengaruhi penilaian terhadap kinerja perusahaan. Manajemen laba merupakan salah satu faktor yang mempengaruhi kinerja perusahaan. Manajemen akan memilih metode tertentu untuk mendapatkan laba yang sesuai dengan motivasinya (Dwi, 2005).

H5: Manajemen laba berpengaruh signifikan terhadap kinerja keuangan

Dari hipotesis yang telah diuraikan, maka berikut ini disajikan model penelitian:

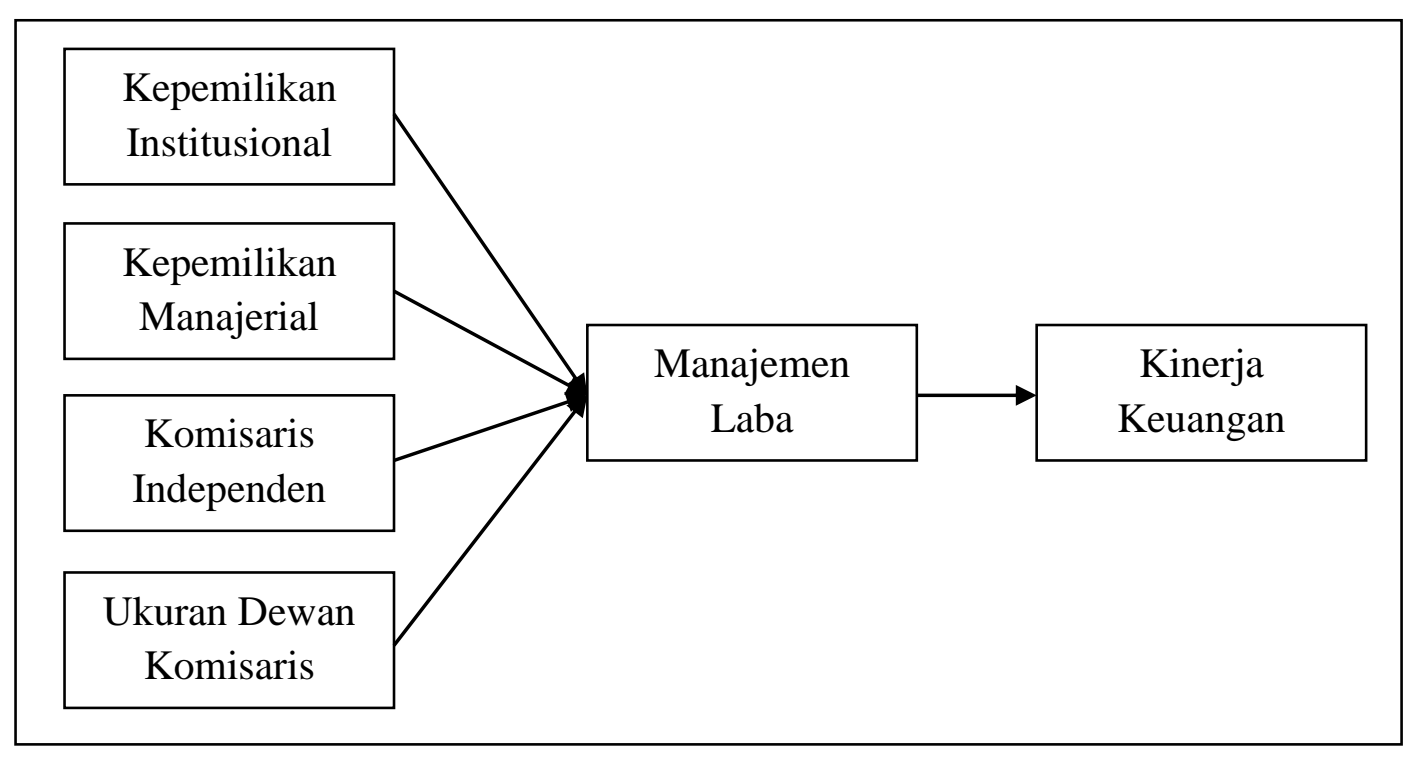

\section{Gambar 1. Model Penelitian}

\section{METODE}


Sampel dan Data. Populasi dalam penelitian ini adalah perusahaan manufaktur yang terdaftar di Bursa Efek Indonesia.Perusahaan yang menjadi sampel dalam penelitian ini dipilih berdasarkan kriteria-kriteria tertentu (purposive sampling), yaitu: a. perusahaan manufaktur yang terdaftar di Bursa Efek Indonesia periode 2012-2014, b. perusahaan manufaktur yang menerbitkan laporan keuangan untuk periode yang berakhir pada tanggal 31 Desember, c. perusahaan manufaktur yang menyajikan laporan keuangan dalam mata uang Rupiah (Rp), d. perusahaan manufaktur yang memperoleh laba selama periode penelitian, e. perusahaan manufaktur yang memiliki data mengenai kepemilikan institusional selama periode penelitian, dan f. perusahaan manufaktur yang memiliki data mengenai kepemilikan manajerial selama periode penelitian.

Identifikasi dan Pengukuran Variabel. Manajemen Laba. Manajemen laba merupakan suatu intervensi dengan maksud tertentu terhadap proses pelaporan keuangan eksternal dengan sengaja untuk memperoleh beberapa keuntungan pribadi. Dechow et al. (dalam Ujiyantho dan Bambang, 2007) mengatakan penggunaan discretionary accruals sebagai proksi manajemen laba dihitung dengan menggunakan Modified Jones Model.

$$
\text { Tait }=\text { Nit }- \text { CFOit }
$$

Nilai total accrual (TA) yang diestimasi dengan persaman regresi OLS sebagai berikut:

$$
\begin{gathered}
\text { TAit/Ait- } 1=\beta 1(1 / \text { Ait- } 1)+\beta 2(\Delta \text { Revit } / \text { Ait- } 1-\Delta \text { Recit } / \text { Ait- } 1)+ \\
\beta 3(\text { PPEit } / \text { Ait- } 1)+e
\end{gathered}
$$

Dengan menggunakan koefisien regresi diatas nilai non discretionary accruals (NDA) dapat dihitung dengan rumus:

$$
\text { NDAit }=\beta 1(1 / \text { Ait-1 })+\beta 2(\Delta \text { Revit } / \text { Ait-1 }-\Delta \text { Recit } / \text { Ait-1 })+\beta 3(\text { PPEit } / \text { Ait- } 1)
$$

Selanjutnya discretionary accrual (DA) dapat dihitung sebagai berikut:

$$
\text { DAit }=\text { TAit } / \text { Ait-1 }- \text { NDAit }
$$

Keterangan:

DAit = Discretionary Accruals perusahaan i pada periode ke $\mathrm{t}$

NDAit $=$ Non Discretionary Accruals perusahaan i pada periode ke $\mathrm{t}$

Tait $=$ Total akrual perusahaan i pada periode ke $\mathrm{t}$

Nit = Laba bersih perusahaan i pada periode ke-t

CFOit $=$ Aliran kas dari aktivitas operasi perusahaan i pada periode ke $\mathrm{t}$

Ait-1 = Total aktiva perusahaan i pada periode ke $\mathrm{t}-1$

$\triangle$ Revit $=$ Perubahan pendapatan perusahaan i pada periode ke $\mathrm{t}$

PPEit $=$ Aktiva tetap perusahaan pada periode ke $\mathrm{t}$

$\Delta$ Recit $=$ Perubahan piutang perusahaan i pada periode ke $\mathrm{t}$

e $\quad=$ error

Kinerja Keuangan. Kinerja keuangan dalam penelitian ini diukur dengan menggunakan Cash Flow Return on Asset (CFROA). CFROA dihitung dari laba sebelum bunga dan pajak ditambah depresiasi dibagi dengan total aktiva (Arief dan Bambang, 2007).

Keterangan:

$$
C F R O A=(E B I T+\text { Dep }) / \text { Assets }
$$

$\begin{array}{ll}\text { CFROA } & =\text { Cash flow return on assets } \\ \text { EBIT } & =\text { Laba sebelum bunga dan pajak } \\ \text { Dep } & =\text { Depresiasi } \\ \text { Asset } & =\text { Total aktiva }\end{array}$


Kepemilikan Institusional. Kepemilikan institusional adalah jumlah persentase hak suara yang dimiliki oleh institusi. Dalam penelitian ini diukur dengan menggunakan indikator persentase jumlah saham yang dimiliki institusi dari seluruh saham yang beredar (Guna dan Arleen, 2010).

Kepemilikan Manajerial. Indikator yang digunakan untuk mengukur kepemilikan manajerial adalah persentase jumlah saham yang dimiliki pihak manajemen dari seluruh saham perusahaan yang beredar (Guna dan Arleen, 2010).

Komisaris Independen. Komisaris independen adalah anggota dewan komisaris yang tidak terafiliasi dengan manajemen, anggota dewan komisaris lainnya dan pemegang saham pengendali, serta bebas dari hubungan bisnis atau hubungan lainnya yang dapat mempengaruhi kemampuannya untuk bertindak independen atau bertindak semata-mata demi kepentingan perusahaan. Proporsi dewan komisaris independen diukur dengan menggunakan indikator persentase anggota dewan komisaris yang berasal dari luar perusahaan dari seluruh anggota dewan komisaris perusahaan (Ujiyantho dan Bambang, 2007).

Ukuran Dewan Komisaris. Beiner, et al (dalam Ujiyantho dan Bambang, 2007) menyatakan ukuran dewan komisaris merupakan jumlah anggota dewan komisaris perusahaan. Dewan komisaris bertanggung jawab dan berwenang mengawasi tindakan manajemen, dan memberikan nasehat kepada manajemen jika dipandang perlu oleh dewan komisaris. Ukuran dewan komisaris diukur dengan menggunakan indikator jumlah anggota dewan komisaris suatu perusahaan (Nasution dan Setiawan, 2007).

\section{HASIL DAN PEMBAHASAN}

Populasi dalam penelitian ini menggunakan sebanyak 131 perusahaan manufaktur yang terdaftar di Bursa Efek Indonesia selama tahun 2012-2014. Pengambilan sampel dilakukan dengan metode purposive sampling berdasarkan kriteria-kriteria tertentu, yang mana hasilnya adalah 29 perusahaan memenuhi kriteria. Total sampel selama 3 tahun adalah sebanyak 87 dengan data outlier sebanyak 14 sehingga yang digunakan adalah 73 .

Hasil Uji Normalitas. Berikut adalah hasil pengujian normalitas untuk persamaan regresi model Ya (pengaruh variabel kepemilikan institusional, kepemilikan manajerial, komisaris independen, dan ukuran dewan komisaris terhadap manajemen laba) yang disajikan pada tabel 1 di bawah ini:

Tabel 1

Hasil Uji Normalitas Model Ya

\begin{tabular}{|l|c|}
\hline & $\begin{array}{c}\text { Unstandardized } \\
\text { Residual }\end{array}$ \\
\hline$N$ & 73 \\
\hline Asymp. Sig. (2-tailed) & 0,958 \\
\hline
\end{tabular}

Sumber: Hasil pengolahan data dengan SPSS 
Hasil pengujian normalitas untuk persamaan regresi model Ya dengan KolmogorovSmirnov test dapat dilihat pada Asymp. Sig. (2-tailed) yang dihasilkan dari unstandardized residual. Variabel residual dinyatakan berdistribusi secara normal jika signifikansi lebih besar dari 5\% atau 0,05. Nilai siginifikansi 0,958 lebih besar dari 0,05 maka dapat dikatakan bahwa uji normalitas terpenuhi.

Berikut adalah hasil pengujian normalitas untuk persamaan regresi model $\mathrm{Yb}$ (pengaruh manajemen laba terhadap kinerja keuangan) yang disajikan pada tabel 2 di bawah ini:

Tabel 2

Hasil Uji Normalitas Model Yb

\begin{tabular}{|l|c|}
\hline & $\begin{array}{c}\text { Unstandardized } \\
\text { Residual }\end{array}$ \\
\hline$N$ & 73 \\
\hline Asymp. Sig. (2-tailed) & 0,707 \\
\hline
\end{tabular}

Sumber: Hasil pengolahan data dengan SPSS

Hasil pengujian normalitas untuk persamaan regresi model $\mathrm{Yb}$ dengan KolmogorovSmirnov test dapat dilihat pada Asymp. Sig. (2-tailed) yang dihasilkan dari unstandardized residual. Variabel residual dinyatakan berdistribusi secara normal jika signifikansi lebih besar dari 5\% atau 0,05. Nilai siginifikansi 0,707 lebih besar dari 0,05 maka dapat dikatakan bahwa uji normalitas terpenuhi.

Hasil Uji Multikolinieritas. Tabel 3 menunjukkan hasil pengujian multikolinieritas untuk persamaan regresi model Ya:

Tabel 3

Hasil Uji Multikolinieritas

\begin{tabular}{|l|c|c|}
\hline & Tolerance & VIF \\
\hline Kepemilikan Institusional & 0,621 & 1,611 \\
\hline Kepemilikan Manajerial & 0,624 & 1,604 \\
\hline Komisaris Independen & 0,901 & 1,110 \\
\hline Ukuran Dewan Komisaris & 0,954 & 1,048 \\
\hline
\end{tabular}

Sumber: Hasil pengolahan data dengan SPSS

Uji multikolinieritas dapat dilihat dari nilai variance inflaction factor (VIF) dan nilai tolerance. Apabila nilai VIF kurang dari 10 dan nilai tolerance lebih dari 0,10 maka dalam model regresi tidak terdapat gejala multikolinieritas.

Berdasarkan tabel di atas maka dapat dilihat model regresi tidak terdapat gejala multikolinieritas. Hal ini berarti bahwa semua variabel bebas yang ada dalam model regresi tidak terjadi korelasi antar variabel dan memenuhi persyaratan untuk digunakan sebagai prediktor.

Hasil Uji Autokorelasi. Berikut adalah hasil pengujian autokorelasi untuk persamaan regresi model Ya yang disajikan pada tabel 4 di bawah ini: 
Tabel 4

Hasil Uji Autokorelasi Model Ya

\begin{tabular}{|c|c|}
\hline Model & Durbin-Watson \\
\hline 1 & 2,203 \\
\hline
\end{tabular}

Sumber: Hasil pengolahan data dengan SPSS

Hasil pengujian autokorelasi untuk persamaan regresi model Ya menunjukkan besarnya nilai Durbin-Watson adalah sebesar 2,203, dimana angka Durbin-Watson berada diantara 1,7375 sampai dengan 4 - 1,7375. Nilai sebesar 1,7375 adalah nilai $D W$ berdasarkan nilai dU pada tabel Durbin-Watson dengan nilai n sebanyak 73 dan nilai k sebanyak 4 variabel, jadi nilai $D W$ berada pada $1,7375<2,203<2,2625$. Hasil tersebut berada di daerah bebas autokorelasi. Dengan demikian hasil uji autokorelasi menunjukkan bahwa model regresi berganda layak untuk digunakan dalam penelitian ini.

Berikut adalah hasil pengujian autokorelasi untuk persamaan regresi model $\mathrm{Yb}$ yang disajikan pada tabel 5 di bawah ini:

\section{Tabel 5}

Hasil Uji Autokorelasi Model Yb

\begin{tabular}{|c|c|}
\hline Model & Durbin-Watson \\
\hline 1 & 2,156 \\
\hline
\end{tabular}

Sumber: Hasil pengolahan data dengan SPSS

Hasil pengujian autokorelasi untuk persamaan regresi model $\mathrm{Yb}$ menunjukkan besarnya nilai Durbin-Watson adalah sebesar 2,156, dimana angka Durbin-Watson berada diantara 1,6479 sampai dengan $4-1,6479$. Nilai sebesar 1,6479 adalah nilai $D W$ berdasarkan nilai dU pada tabel Durbin-Watson dengan nilai n sebanyak 73 dan nilai k sebanyak 1 variabel, jadi nilai $D W$ berada pada $1,6479<2,156<2,3521$. Hasil tersebut berada di daerah bebas autokorelasi. Dengan demikian hasil uji autokolinieritas menunjukkan bahwa model regresi berganda layak untuk digunakan dalam penelitian ini.

Hasil Uji Heteroskedastisitas. Berikut adalah hasil pengujian heteroskedastisitas untuk persamaan regresi model Ya yang disajikan pada tabel 6 di bawah ini:

\section{Tabel 6}

Hasil Uji Heteroskedastisitas Model Ya

\begin{tabular}{|l|c|c|}
\hline & $t$ & Sig \\
\hline (Constant) & $-4,381$ & 0,000 \\
\hline Kepemilikan Institusional & 0,993 & 0,324 \\
\hline Kepemilikan Manajerial & 1,144 & 0,257 \\
\hline Komisaris Independen & $-1,399$ & 0,166 \\
\hline Ukuran Dewan Komisaris & 0,582 & 0,562 \\
\hline
\end{tabular}

Sumber: Hasil pengolahan data dengan SPSS

Hasil pengujian heteroskedastisitas untuk persamaan regresi model Ya menunjukkan nilai signifikan untuk variabel kepemilikan institusional sebesar 0,324, kepemilikan manajerial sebesar 0,257, komisaris independen sebesar 0,166, dan ukuran dewan 
komisaris sebesar 0,562. Berdasarkan uraian diatas nilai signifikansi untuk semua variabel lebih besar dari 0,05 . Dengan demikian bahwa model regresi dalam penelitian ini tidak memiliki gejala heteroskedastisitas.

Berikut adalah hasil pengujian heteroskedastisitas untuk persamaan regresi model $\mathrm{Yb}$ yang disajikan pada tabel 7 di bawah ini:

Tabel 7

Hasil Uji Heteroskedastisitas Model Yb

\begin{tabular}{|l|c|c|}
\hline \multicolumn{1}{|c|}{ Model } & $T$ & Sig \\
\hline (Constant) & $-11,396$ & 0,000 \\
\hline Manajemen Laba & $-1,863$ & 0,067 \\
\hline
\end{tabular}

Sumber: Hasil pengolahan dengan data SPSS

Hasil pengujian heteroskedastisitas untuk persamaan regresi model $\mathrm{Yb}$ menunjukkan nilai signifikan sebesar 0,067 dimana nilai tersebut lebih besar dari 0,05. Dengan demikian bahwa model regresi dalam penelitian ini tidak memiliki gejala heteroskedastisitas.

\section{Hasil Pengujian Hipotesis}

Uji Secara Simultan (Uji F). Berikut adalah hasil uji F untuk melihat pengaruh variabel kepemilikan institusional, kepemilikan manajerial, komisaris independen, dan ukuran dewan komisaris secara bersama-sama terhadap manajemen laba (model Ya) yang disajikan pada tabel 8 di bawah ini:

\section{Tabel 8}

\begin{tabular}{|l|c|c|}
\multicolumn{3}{|c}{ Hasil Uji F Model Ya } \\
\begin{tabular}{|c|c|c|}
\hline Model & F & Sig. \\
\hline Regression & 2,781 & 0,033 \\
\hline
\end{tabular}
\end{tabular}

Sumber: Hasil pengolahan data dengan SPSS

Hasil uji $\mathrm{F}$ di atas menunjukkan nilai signifikan sebesar 0,033 dimana nilai signifikan tersebut lebih kecil dari 0,05. Dengan demikian dapat disimpulkan bahwa terdapat pengaruh yang signifikan dari variabel kepemilikan institusional, kepemilikan manajerial, komisaris independen, dan ukuran dewan komisaris secara bersama-sama terhadap manajemen laba dengan tingkat keyakinan $95 \%$.

Berikut adalah hasil uji $\mathrm{F}$ untuk melihat pengaruh variabel manajemen laba terhadap kinerja keuangan (model $\mathrm{Yb}$ ) yang disajikan pada tabel 9 di bawah ini:

\section{Tabel 9}

Hasil Uji F Model Yb

\begin{tabular}{|c|c|c|}
\hline Model & F & Sig. \\
\hline Regression & 4,391 & 0,040 \\
\hline
\end{tabular}

Sumber: Hasil pengolahan data dengan SPSS 
Hasil uji $\mathrm{F}$ pada tabel 9 menunjukkan bahwa nilai signifikan adalah sebesar 0,040 dimana nilai signifikan tersebut lebih kecil dari 0,05. Dengan demikian dapat disimpulkan bahwa terdapat pengaruh yang signifikan dari variabel manajemen laba terhadap kinerja keuangan dengan tingkat keyakinan $95 \%$.

Uji Secara Parsial (Uji t). Berikut adalah hasil uji t untuk melihat pengaruh variabel kepemilikan institusional, kepemilikan manajerial, komisaris independen, dan ukuran dewan komisaris secara parsial terhadap manajemen laba (Model Ya) yang disajikan pada tabel 10 di bawah ini:

Tabel 10

Hasil Uji t Model Ya

\begin{tabular}{|l|c|c|}
\hline \multicolumn{1}{|c|}{ Model } & $\mathrm{t}$ & Sig. \\
\hline Constant & 0,316 & 0,753 \\
\hline Kepemilikan Institusional & 0,455 & 0,650 \\
\hline Kepemilikan Manajerial & 2,513 & 0,014 \\
\hline Komisaris Independen & 0,327 & 0,745 \\
\hline Ukuran Dewan Komisaris & 2,411 & 0,019 \\
\hline
\end{tabular}

Sumber: Hasil pengolahan data dengan SPSS

Hasil uji t untuk melihat pengaruh dari variabel kepemilikan institusional, kepemilikan manajerial, komisaris independen, dan ukuran dewan komisaris secara parsial terhadap manajemen laba menunjukkan bahwa nilai signifikan untuk variabel kepemilikan institusional adalah sebesar 0,650 dimana nilai tersebut lebih besar dari 0,05. Hasil tersebut menunjukkan bahwa H1 ditolak. Dengan demikian kepemilikan insitusional tidak terdapat pengaruh yang signifikan terhadap manajemen laba. Hasil penelitian ini sesuai dengan Arief dan Bambang (2007), bahwa kepemilikan institusional tidak terdapat pengaruh yang signifikan terhadap manajemen laba. Hal ini menjelaskan bahwa kepemilikan institusional dalam suatu perusahaan belum mampu mengurangi praktik manajemen laba dalam perusahaan tersebut, kemungkinan dikarenakan adanya perbedaan kepentingan. Institusi mengadakan kontrak dengan manajemen dalam upaya memaksimumkan kesejahteraannya dengan harapan tingkat profitabilitas yang selalu meningkat, sedangkan manajemen bertanggungjawab untuk memaksimumkan kesejahteraan para pemegang saham. Namun di sisi lain, manajemen juga ingin memaksimumkan kesejahteraannya sendiri, misalnya dengan mendapatkan pinjaman, investasi, kompensasi, bonus. Perbedaan kepentingan inilah yang menyebabkan manajemen lebih mementingkan kepentingan perusahaan daripada menyejahterakan para pemegang saham sehingga kerap kali manajemen melakukan manajemen laba.

Kepemilikan manajerial memiliki nilai signifikan sebesar 0,014 dimana nilai tersebut lebih kecil dari 0,05. Hasil tersebut menunjukkan bahwa H2 diterima. Dengan demikian kepemilikan manajerial terdapat pengaruh yang signifikan terhadap manajemen laba. Hasil penelitian ini sesuai dengan Arief dan Bambang (2007), bahwa kepemilikan manajerial memiliki pengaruh yang signifikan terhadap manajemen laba.

Komisaris independen memiliki nilai signifikan sebesar 0,745 dimana nilai tersebut lebih besar dari 0,05. Hasil tersebut menunjukkan bahwa H3 ditolak. Dengan demikian komisaris independen tidak memiliki pengaruh yang signifikan terhadap manajemen laba. 
Hasil penelitian ini sesuai dengan Guna dan Arleen (2010), bahwa komisaris independen tidak memiliki pengaruh yang signifikan terhadap manajemen laba. Hal ini menjelaskan bahwa komisaris independen dalam suatu perusahaan belum mampu mengurangi praktik manajemen laba dalam perusahaan dikarenakan kemungkinan terdapat motivasi manajemen yang salah, misalnya setiap perusahaan ingin memberikan informasi yang terbaik tentang prospek masa depan perusahaan kepada para investor. Untuk mencapai tujuan tersebut maka manajemen akan berusaha melakukan manajemen laba. Dengan memberikan informasi yang baik pada kekuatan laba, maka dapat meningkatkan nilai pasar saham perusahaan.

Ukuran dewan komisaris memiliki nilai signifikan sebesar 0,019 dimana nilai tersebut lebih kecil dari 0,05. Hasil tersebut menunjukkan bahwa H4 diterima. Dengan demikian ukuran dewan komisaris memiliki pengaruh yang signifikan terhadap manajemen laba. Hasil penelitian ini sesuai dengan Nasution dan Setiawan (2007), bahwa ukuran dewan komisaris memiliki pengaruh yang signifikan terhadap manajemen laba.

Berikut adalah hasil uji t untuk melihat pengaruh dari variabel manajemen laba terhadap kinerja keuangan yang disajikan pada tabel 11 di bawah ini:

Tabel 11

Hasil Uji t Model Yb

\begin{tabular}{|l|c|c|}
\hline \multicolumn{1}{|c|}{ Model } & $\mathrm{t}$ & Sig. \\
\hline Constant & 10,809 & 0,000 \\
\hline Manajemen Laba & $-2,095$ & 0,040 \\
\hline
\end{tabular}

Sumber: Hasil pengolahan data dengan SPSS

Hasil uji t pada tabel 11 diatas menunjukkan nilai signifikan sebesar 0,040 sama seperti hasil uji $\mathrm{F}$ dimana nilai tersebut lebih kecil dari 0,05 . Hasil tersebut menunjukkan bahwa H5 diterima. Dengan demikian manajemen laba memiliki pengaruh yang signifikan terhadap kinerja keuangan. Hasil penelitian ini sesuai dengan Dwi (2005), bahwa manajemen laba memiliki pengaruh yang signifikan terhadap kinerja keuangan.

Uji Korelasi (R). Berikut adalah hasil uji korelasi (R) untuk persamaan regresi model Ya yang disajikan pada tabel 12 di bawah ini:

Tabel 12

Hasil Uji Korelasi (R) Model Ya

\begin{tabular}{|c|c|}
\hline Model & $R$ \\
\hline 1 & 0,375 \\
\hline
\end{tabular}

Sumber: Hasil pengolahan data dengan SPSS

Hasil uji korelasi (R) untuk persamaan regresi model Ya menunjukkan bahwa nilai $\mathrm{R}$ adalah sebesar 0,375 dimana hasil dari nilai $\mathrm{R}$ tersebut menunjukkan bahwa hubungan variabel independen dengan variabel dependen adalah hubungan korelasi moderat dan positif.

Berikut adalah hasil uji korelasi $(\mathrm{R})$ untuk persamaan regresi model Yb yang disajikan pada tabel 13 di bawah ini: 
Tabel 13

Hasil Uji Korelasi (R) Model Yb

\begin{tabular}{|c|c|}
\hline Model & $R$ \\
\hline 1 & 0,241 \\
\hline
\end{tabular}

Sumber: Hasil pengolahan data dengan SPSS

Hasil uji korelasi $(\mathrm{R})$ untuk persamaan regresi model $\mathrm{Yb}$ menunjukkan bahwa nilai $\mathrm{R}$ adalah sebesar 0,241 dimana hasil dari nilai $\mathrm{R}$ tersebut menunjukkan bahwa hubungan variabel independen dengan variabel dependen adalah hubungan korelasi rendah dan positif.

Uji Koefisien Determinasi $\left(\mathbf{R}^{2}\right)$. Berikut adalah hasil uji koefisien determinasi $\left(\mathrm{R}^{2}\right)$ untuk persamaan regresi model Ya yang disajikan pada tabel 14 di bawah ini:

\section{Tabel 14}

Hasil Uji Koefisien Determinasi $\left(\mathrm{R}^{2}\right)$ Model Ya

\begin{tabular}{|c|c|}
\hline Model & Adjusted $R$ Square \\
\hline 1 & 0,090 \\
\hline \multicolumn{2}{|c|}{ Sumber: Hasil pengolahan data dengan SPSS }
\end{tabular}

Hasil uji koefisien determinasi $\left(\mathrm{R}^{2}\right)$ untuk persamaan regresi model Ya menunjukkan bahwa nilai $\mathrm{R}^{2}$ adalah sebesar 0,090 . Hal ini berarti sebesar $9 \%$ variasi manajemen laba dapat dijelaskan oleh variasi variabel independen yaitu kepemilikan institusional, kepemilikan manajerial, komisaris independen, dan ukuran dewan komisaris. Sisanya sebesar $91 \%(100 \%$ - 9\%) variasi yang terjadi atas manajemen laba dapat dijelaskan oleh variabel lainnya di luar model regresi.

Berikut adalah hasil uji koefisien determinasi $\left(\mathrm{R}^{2}\right)$ untuk persamaan regresi model $\mathrm{Yb}$ yang disajikan pada tabel 15 di bawah ini:

Tabel 15

Hasil Uji Koefisien Determinasi $\left(\mathrm{R}^{2}\right)$ Model $\mathrm{Yb}$

\begin{tabular}{|c|c|}
\hline Model & $R$ Square \\
\hline 1 & 0,058 \\
\hline
\end{tabular}

Sumber: Hasil pengolahan data dengan SPSS

Hasil uji koefisien determinasi $\left(\mathrm{R}^{2}\right)$ untuk persamaan regresi model $\mathrm{Yb}$ menunjukkan bahwa nilai $\mathrm{R}^{2}$ adalah sebesar 0,058 . Hal ini berarti sebesar 5,8\% variasi kinerja keuangan dapat dijelaskan oleh variasi variabel independen yaitu manajemen laba. Sisanya sebesar $94,2 \%(100 \%-5,8 \%)$ variasi yang terjadi atas kinerja keuangan dapat dijelaskan oleh variabel lainnya di luar model regresi.

\section{PENUTUP}

Kesimpulan. Tujuan penelitian ini adalah untuk memperoleh bukti empiris mengenai pengaruh kepemilikan institusional, kepemilikan manajerial, komisaris independen, ukuran dewan komisaris terhadap manajemen laba dan pengaruh manajemen laba terhadap 
kinerja keuangan. Hasil pengujian dari keempat uji asumsi klasik yang dilakukan menyatakan bahwa model regresi layak digunakan untuk memprediksi nilai manajemen laba dan kinerja keuangan. Sementara itu, berdasarkan hasil pengujian hipotesis yang dilakukan secara simultan dengan uji $\mathrm{F}$ menyimpulkan bahwa keempat variabel independen, yaitu kepemilikan institusional, kepemilikan manajerial, komisaris independen, dan ukuran dewan komisaris secara bersama-sama memiliki pengaruh yang signifikan terhadap manajemen laba.

Berdasarkan hasil pegujian hipotesis yang dilakukan secara parsial dengan uji $t$ menyimpulkan bahwa variabel kepemilikan manajerial dan ukuran dewan komisaris memiliki pengaruh yang signifikan terhadap manajemen laba, sedangkan variabel kepemilikan institusional dan komisaris independen tidak memiliki pengaruh yang signifikan terhadap manajemen laba. Selain itu manajemen laba memiliki pengaruh yang signifikan terhadap kinerja keuangan.

Hasil penelitian mengenai pengaruh variabel kepemilikan institusional terhadap manajemen laba menunjukkan bahwa tidak ada pengaruh yang signifikan antara kepemilikan institusional dengan manajemen laba. Hasil penelitian ini sesuai dengan penelitian yang dilakukan oleh Ujiyantho dan Bambang (2007) yang menunjukkan bahwa kepemilikan institusional tidak memiliki pengaruh yang signifikan terhadap manajemen laba, tetapi hasil penelitian ini berlawanan dengan penelitian yang dilakukan oleh Asrori dan Bowo (2014) yang menunjukkan bahwa kepemilikan institusional berpengaruh signifikan terhadap manajemen laba.

Hasil penelitian mengenai pengaruh variabel kepemilikan manajerial terhadap manajemen laba menunjukkan bahwa terdapat pengaruh yang signifikan antara kepemilikan institusional dengan manajemen laba. Hasil penelitian ini sesuai dengan penelitian yang dilakukan oleh Ujiyantho dan Bambang (2007) yang menunjukkan bahwa kepemilikan manajerial memiliki pengaruh yang signifikan terhadap manajemen laba, tetapi hasil penelitian ini berlawanan dengan penelitian yang dilakukan oleh Guna dan Arleen (2010) yang menunjukkan bahwa kepemilikan manajerial tidak berpengaruh signifikan terhadap manajemen laba.

Hasil penelitian mengenai pengaruh variabel komisaris independen terhadap manajemen laba menunjukkan bahwa tidak ada pengaruh yang signifikan antara komisaris independen dengan manajemen laba. Hasil penelitian ini sesuai dengan penelitian yang dilakukan oleh Guna dan Arleen (2010) yang menunjukkan bahwa komisaris independen tidak memiliki pengaruh yang signifikan terhadap manajemen laba, tetapi hasil penelitian ini berlawanan dengan penelitian yang dilakukan oleh Ujiyantho dan Bambang (2007) yang menunjukkan bahwa komisaris independen berpengaruh signifikan terhadap manajemen laba.

Hasil penelitian mengenai pengaruh variabel ukuran dewan komisaris terhadap manajemen laba menunjukkan bahwa terdapat pengaruh yang signifikan antara ukuran dewan komisaris dengan manajemen laba. Hasil penelitian ini sesuai dengan penelitian yang dilakukan oleh Nasution dan Setiawan (2007) yang menunjukkan bahwa ukuran dewan komisaris memiliki pengaruh yang signifikan terhadap manajemen laba, tetapi hasil penelitian ini berlawanan dengan penelitian yang dilakukan oleh Ujiyantho dan Bambang (2007) yang menunjukkan bahwa ukuran dewan komisaris tidak berpengaruh signifikan terhadap manajemen laba.

Hasil penelitian mengenai pengaruh variabel manajemen laba terhadap kinerja keuangan menunjukkan bahwa terdapat pengaruh yang signifikan antara manajemen laba 
dengan kinerja keuangan. Hasil penelitian ini sesuai dengan penelitian yang dilakukan oleh Dwi (2005) yang menunjukkan bahwa manajemen laba memiliki pengaruh yang signifikan terhadap kinerja keuangan, tetapi hasil penelitian ini berlawanan dengan penelitian yang dilakukan oleh Ujiyantho dan Bambang (2007) yang menunjukkan bahwa manajemen laba tidak berpengaruh signifikan terhadap kinerja keuangan.

Saran. Penelitian ini menggunakan empat variabel independen, yaitu kepemilikan institusional, kepemilikan manajerial, komisaris independen, dan ukuran dewan komisaris, serta terdapat dua variabel dependen, yaitu manajemen laba dan kinerja keuangan yang dilakukan pada perusahaan manufaktur yang terdaftar di Bursa Efek Indonesia pada periode 2012-2014. Berdasarkan hasil penelitian yang dilakukan, ada beberapa keterbatasan dalam penelitian, yaitu: pertama, penelitian ini menggunakan sampel pada perusahaan manufaktur yang terdaftar di Bursa Efek Indonesia sehingga tidak bisa dijadikan acuan secara menyeluruh mengenai faktor-faktor apa saja yang dapat menyebabkan terjadinya manajemen laba serta kinerja keuangan. Kedua, penelitian ini menggunakan rentang waktu yang relatif singkat yaitu hanya pada tahun 2012-2014 sehingga hasilnya mungkin hanya memberikan gambaran yang bersifat situasional pada periode tersebut. Ketiga, perhitungan untuk manajemen laba hanya menggunakan model akrual saja dan untuk perhitungan kinerja keuangan hanya menggunakan proksi cash flow return on asset (CFROA) sehingga kurang dapat diperbandingkan. Keempat, penelitian ini hanya menggunakan empat variabel independen, yaitu kepemilikan institusional, kepemilikan manajerial, komisaris independen, dan ukuran dewan komisaris untuk menjelaskan variabel manajemen laba.

Dari keterbatasan yang ada selama dilakukan penelitian, maka disarankan bagi penelitian selanjutnya untuk memperluas sampel penelitian tidak hanya pada sektor manufaktur saja, tetapi bisa dari berbagai sektor lainnya sehingga hasil penelitian dapat digeneralisasi bagi seluruh perusahaan. Disarankan bagi penelitian selanjutnya untuk menambahkan periode penelitian yang lebih panjang, sehingga hasil penelitian dapat menunjukkan hasil yang lebih akurat. Disarankan bagi penelitian selanjutnya agar menggunanakn proksi lain untuk mengukur manajemen laba dan kinerja keuangan agar lebih mudah diperbandingkan. Disarankan bagi penelitian selanjutnya untuk menambah variabel independen yang lain untuk menjelaskan variabel manajemen laba, misalnya variabel komite audit, leverage, profitabilitas, dan ukuran perusahaan.

\section{DAFTAR RUJUKAN}

Asrori, Kiswanto dan Bowo Sumanto. (2014). Pengaruh Kepemilikan Institusional dan Ukuran Dewan Komisaris Terhadap Manajemen Laba. Accounting Analysis Journal. Vol. 3.(1). hal 45-48

Boediono, S.B. (2005). Kualitas Laba: Studi Pengaruh Mekanisme Corporate Governance dan Dampak Manajemen Laba dengan Menggunakan Analisis Jalur. Simposium Nasional Akuntansi VIII. Solo. hal. 172-178

Cornett, et al. (2006). Earnings Management, Corporate Governance, and True $156-157$

Financial Performance. Simposium Nasional Akuntansi VII. Semarang. hal. 
Darmawati, Deni, Khomsiyah dan Rika Rahayu. (2005). Hubungan Corporate Governance dan Kinerja Perusahaan. Simposium Nasional Akuntansi VII. Jakarta. hal. 78-81

Duwi, Priyatno. (2009). SPSS Untuk Analisis Korelasi, Regresi, dan Multivariate. Yogyakarta: Gava Media

Dwi, Theresia. (2005). Hubungan antara Good Corporate Governance dan Struktur

Kepemilikan Dengan Kinerja Keuangan Studi Kasus pada Perusahaan yang listing di Bursa Efek Jakarta. Simposium Nasional Akuntansi VIII. Makasar.

Emrinaldi. (2007). Analisis Pengaruh Praktik Tata Kelola Perusahaan (Corporate Governance) terhadap Kesulitan Keuangan Perusahaan (Financial Distress): Suatu Kajian Empiris. Jurnal Bisnis dan Akuntansi. Vol. 9. (1).hal. 88-108

Ghozali, Imam. (2013). Aplikasi Analisis Multivariate dengan Program IBM SPSS 21 Update PLS Regresi. Edisi 7. Semarang: Badan Penerbit Universitas Diponegoro Gideon, Boediono. (2005). Pengaruh Mekanisme Corporate Governace dan Dampak Manajemen Laba dengan Analisis Jalur. Simposium Nasional Akuntansi VIII. Jakarta. hal. 172-178

Guna, Welvin dan Arleen Herawaty. (2010). Pengaruh Mekanisme Good Corporate Governance, Independensi Auditor, Kualitas Audit dan Faktor Lainnya Terhadap Manajemen Laba. Jurnal Bisnis dan Akuntansi. Vol. 12. (1). hal. 53-68

Iqbal, Syaiful. (2007). Corporate Governance Sebagai Alat Pereda Praktik Manajemen Laba (Earnings Management). Accounting Analysis Journal. hal. 94-97

Kieso E. Donald, Weygandt J. Jerry dan Terry D. (2007). Intermediate Accounting. Twelfth Edition. New York: John Willey \& Sons

Luayyi, Sri. (2010). Teori Keagenan dan Manajemen Laba dari Sudut Pandang Etika Manajer. Jurnal Akuntansi dan Keuangan. Vol 1. (2). Hal. 15-18

Najib. (2010). Pengaruh Manajemen Keuangan terhadap Nilai Perusahaan. Jurnal Riset Akuntansi. Vol 4. (1). Hal. 13-15

Nasution, Marihot dan Doddy Setiawan. (2007). Pengaruh Corporate Governance Terhadap Manajemen Laba di Industri Perbankan Indonesia. Simposium Nasional Akuntansi X. Makasar. hal. 2-11

Pradhono dan Yulius Jogi Cristiawan. (2005). Pengaruh Economic Value Added, Residual Income, Earnings dan Arus Kas Operasi terhadap Return yang diterima oleh Pemegang Saham Studi pada perusahaan manufaktur yang terdaftar di Bursa Efek Jakarta. Jurnal Akuntansi dan Keuangan. Vol. 6. $\quad$ (2). hal. 140-166

Purwandari, Indri Wahyu. (2011). Analisis Pengaruh Mekanisme Good Corporate Governance, Profitabilitas, dan Leverage Terhadap Praktek Manajemen Laba

(Earning Management). Simposium Nasional Akuntansi XI. Semarang

RI. (2007). Undang-Undang No. 40 tentang Perseroan Terbatas

Subramanyam, dan Jhon. J. Wild. (2010). Analisis Laporan Keuangan. Edisi Sepuluh. Jakarta: Salemba Empat

Sulistyanto, Sri. (2008). Manajemen Laba, Teori dan Model Empiris. Jakarta: PT Grasindo

Susiana dan A. Herawaty. (2007). Analisis Pengaruh Independensi, Mekanisme Corporate Governance, dan Kualitas Audit Terhadap Integritas Laporan Keuangan. Simposium Nasional Akuntansi X. Makassar 
Tarjo. (2008). Pengaruh Konsentrasi Kepemilikan Institusional dan Leverage Terhadap Manajemen Laba, Nilai Pemegang Saham serta Cost of Equity Capital. Simposium Nasional Akuntansi XI. Pontianak

Ujiyantho, M. Arief dan Bambang Agus Pramuka. (2007). Menaknisme Corporate Governance, Manajemen Laba dan Kinerja Keuangan Studi Pada Perusahaan Go Publik Sektor Manufaktur. Simposium Nasional Akuntansi X. Makasar. hal. 2-13

Wisnu, Arwindo Irawan. 2013. Analisis Pengaruh Kepemilikan Institusional, Leverage, Ukuran Perusahaan Dan Profitabilitas Terhadap Manajemen Laba.

Accounting Analysis Journal. hal. 38-49 